Central European Review of Economics \& Finance

Vol. 28, No. 6 (2018), pp. 63-76

DOI: $10.24136 /$ ceref.2018.032

Received: 10 November 2018. Accepted: 15 December 2018.

Joanna BUGAJEWSKA ${ }^{1}$

\title{
THE FINANCIAL SITUATION OF THE HOUSEHOLDS IN POLAND AFTER IMPLEMENTATION OF THE PROGRAMME „FAMILY 500+”
}

The aim of the present paper is an analysis of the impact of the government economic instrument, the „Family 500+" programme on spending decisions of Polish people. For this purpose, financial conditions of families living in two Polish cities: Radom and Chełm were being observed (in the light of the own diagnosis). As a part of a survey, people were asked questions regarding the amount of monthly family income, savings and credits, types of goods and services purchased owing to the "500+" programme for the benefit of children and young people under 18. The paper ends with conclusions resulting from the conducted research.

Keywords: family policy, „500+” programme, financial decisions.

JEL Classification Codes: H53.

\section{Introduction}

The role of the state in creating Polish family policy is to shape conducive conditions to implement basic family tasks. Social interest in the family results from the fact that it is the potential for the future labour resources, which is a necessary factor for the economic development of the state. The role of family results from its social roles, while in the processes of economic development it has quantitative and qualitative dimensions.

\footnotetext{
${ }^{1}$ MA, Ph.D. Student, K. Pulaski University of Technology and Humanities in Radom, Faculty of Economics and Legal Sciences.
} 
This is why it is so important to define precisely the directions in which it should be implemented, in order to be effective and efficient, and the outlays from the state budget incurred for its implementation spent in a rational way (Durasiewicz 2014, p. 102).

\section{Family policy as a response to the needs of the modern family}

The family is a group of people separated within the household on the basis of biological criteria, and the inclusion of a particular individual into the family is the result of joint living and adding the income (Giza-Poleszczuk, 2005, p. 50). The primary purpose of family life is to enable people to realize themselves best by creating conducive conditions and providing adequate means. Thus, the level and quality of the tasks fulfilled by a family determines the style and form of life of its members. That is why the care function, including activities in the field of emotional sphere and material security, play such an important role in the family structure.

The proper fulfilment of the upbringing role by the family contributes to shaping own values in young people (through showing the right behaviour patterns), learning how to achieve life goals (thanks to the ability to experience the world) and being in relationships with other inhibitants. Thus, children are, to a large extent, a mirror image of their parents.

In most cases a family as a community is able to deal with its duties. However, the problems of the everyday life, i. e.: unemployment, difficult working conditions and low pay, resignation from domestic life for the sake of professional duties can bring real difficulties impossible to tackle without support. So the well-being of the family is guarded by the state, which is able to minimize these difficulties through its permissions and tools. (Durasiewicz, 2009, p. 58).

The state as a subject of family policy has a fundamental impact on all of the instruments that can be activated in order to create proper conditions for the family; for its creation, development, functioning and fulfilment of all socially important roles (Golinowska, 2007, p. 8). One of such instruments is the „Family $500+$ " programme as it is fundamental for improvement of the financial situation of a Polish family. Additional monthly income allows families easier access to goods and services.

According to the Act, this state benefit is designed to cover partially the expenses related to raising a child, including taking care of and satisfying the life needs. The benefit is payable to the mother, father, child's actual guardian or child's legal guardian until the child reaches the age of 18. The amount of this aid equals to PLN 500,00 per month for a child in a family, along with taking into account the conditions for its granting. For families applying for "500+” for the first child, the family income is taken into account. Calculated per person, the amount cannot exceed PLN 800,00. If a child with disability is the family member, the „500+" is available to the first child for the family with the income not exceeding PLN 1,200.00 per person. 
According to Polish Ministry of Family, Labour and Social Policy data, by the end of December 2017, the support of the governmental programme „500+" covered almost 3.82 million children up to 18 years, which is nationwide $55 \%$ of all children up to 18 years. They received over PLN 19 billion. In rural areas this percentage reached $63 \%$, in urban communes $48 \%$, and in urban - rural communes $58 \%$. Single kids of well-situated families were not included.

Accordingly, 2.56 million families received the support from the government's programme „500+”, including around 360,000 large families, over 388,000 single parents and 128,800 families with a disabled child. Most of the beneficiary of the money from „500+" were children in Mazovia (over 552,5 thousand), Silesia (over 382,700) and in Greater Poland (over 378,600).

\section{Family policy in the light of own research}

The main measures of households wealth are their income, accumulated capital and loans. High level of earnings and investments along with low indebtedness condition meeting the current needs of the family and its ability to accumulate funds, and thus proper functioning in the environment. That is why the ability to manage one's own financial resources is such an important factor in the life of every person.

The purpose of the present analysis is to examine family competences in the field of managing the home budget and the ability to spend funds from the „500+” programme by Polish families. The questionnaire contained 19 multiple choice questions. The study was attended by 52 inhibitants from two cities of Chełm and Radom who received the government economic instrument, the „500+" programme, from 1 April 2016 to 30 September 2017.

The respondents were divided into two groups: the beneficiaries of the „500+” programme and the people whose income allowed independent home maintenance.

The analysis was made according to:

1) age and education of beneficiaries,

2) financial situation of families,

3) level of life of children and young people under 18,

4) "the feelings" of the respondents in terms of their material possessions.

According to the study conducted in 2016, the dominant number of inhabitants of Chełm and Radom were people independently maintaining their households. Professionally active people accounted for $58 \%$ of respondents in Chełm and $66 \%$ in Radom. Beneficiaries of social welfare accounted for $42 \%$ of respondents in Chełm and $34 \%$ in Radom. 
Table 1. Division into respondents receiving social welfare benefits and respondents independently maintaining their households [\%]

\begin{tabular}{|l|c|c|}
\hline \multicolumn{1}{|c|}{ Specification } & Chelm & Radom \\
\hline People receiving social welfare benefits & 42 & 34 \\
\hline People independently maintaining their households & 58 & 66 \\
\hline
\end{tabular}

Source: own study based on the conducted surveys.

Most of the respondents who were professionally active had higher education, i.e. $47 \%$ of respondents in Chełm and Radom. A large share of respondents were people with secondary qualifications, i.e. $33 \%$ in Chełm and $29 \%$ in Radom. In Chełm, professionally active respondents were people aged $40-45$ (47\% of respondents). In Radom, respondents not receiving state benefits were mostly people aged 30-35 (35\% of respondents). The professional activity of respondents resulted from their ability to move around the labour market and their ease of using knowledge acquired during their studies and in professional practice.

The analysis shows that work in the lives of these people played an important role. It gave the chance for a better life and was a stimulus for action in further personal development.

If it comes to beneficiaries of social welfare, they were young people aged 30-35 (35\% in Chełm and 22\% in Radom) and aged $36-45$ (29\% in Radom and $45 \%$ in Chełm), mainly with secondary education (73\% in Chełm and 33\% in Radom) or professional (18\% in Chełm and $22 \%$ in Radom). This group of respondents consisted of people having difficulties adapting to the requirements of the local labour market and showed lack of willingness to engage in effective job search. As a result, despite the physical and psychological abilities giving them the opportunity to earn money, they consciously decided to stay in the group of unemployed people, thus charging the state budget with the costs of their subsistence.

Table 2. Age of professionally active people and social welfare beneficiaries [\%]

\begin{tabular}{|c|c|c|c|c|}
\hline Age & $\begin{array}{c}\text { Chelm working } \\
\text { respondents }\end{array}$ & $\begin{array}{c}\text { Radom working } \\
\text { respondents }\end{array}$ & $\begin{array}{c}\text { Radom social welfare } \\
\text { beneficiaries }\end{array}$ & $\begin{array}{c}\text { Chelm social welfare } \\
\text { beneficiaries }\end{array}$ \\
\hline $20-25$ & 0 & 6 & 11 & 0 \\
\hline $26-29$ & 7 & 12 & 22 & 9 \\
\hline $30-35$ & 13 & 35 & 22 & 63 \\
\hline $36-39$ & 33 & 17 & 11 & 9 \\
\hline $40-45$ & 47 & 12 & 34 & 0 \\
\hline $46-50$ & 0 & 12 & 0 & 0 \\
\hline over 50 & 0 & 6 & 0 & 100 \\
\hline Total & 100 & 100 & 100 & 0 \\
\hline
\end{tabular}

Source: own study based on the conducted surveys. 
Table 3. Education of professionally active people and social welfare beneficiaries [\%]

\begin{tabular}{|l|c|c|c|c|}
\hline Education & $\begin{array}{c}\text { Chelm working } \\
\text { respondents }\end{array}$ & $\begin{array}{c}\text { Radom working } \\
\text { respondents }\end{array}$ & $\begin{array}{c}\text { Radom social welfare } \\
\text { beneficiaries }\end{array}$ & $\begin{array}{c}\text { Chelm social welfare } \\
\text { beneficiaries }\end{array}$ \\
\hline Primary & 0 & 6 & 0 & 0 \\
\hline Vocational & 20 & 18 & 22 & 18 \\
\hline Secondary & 33 & 29 & 67 & 73 \\
\hline Higher & 47 & 47 & 11 & 9 \\
\hline Total & 100 & 100 & 100 & 100 \\
\hline
\end{tabular}

Source: own study based on the conducted surveys.

The financial conditions of families in Chelm and Radom in 2016 were influenced by six factors: type of work performed, income preceding time of the survey, number of people in the family, liabilities, accumulated savings and way of managing the financial budget of a household.

According to the conducted survey, professionally active respondents were families in which two adults were formally working (18\% in Radom and $20 \%$ in Chełm), or one person ( $41 \%$ in Radom and $67 \%$ in Chełm) and the family undertook other activities to ensure maintenance funds.

The group of social welfare beneficiaries mainly consisted of families where one person worked professionally (67\% in Radom and 63\% in Chełm), while the other performed odd jobs ( $11 \%$ in Radom and $27 \%$ in Chełm). As a result, the lack of permanent employment, and thus the documented income, provided the opportunity to benefit from social welfare benefits.

Table 4. Forms of earning by professionally active people and social welfare beneficiaries [\%]

\begin{tabular}{|l|c|c|c|c|}
\hline \multicolumn{1}{|c|}{ Specification } & $\begin{array}{c}\text { Radom working } \\
\text { respondents }\end{array}$ & $\begin{array}{c}\text { Chelm working } \\
\text { respondents }\end{array}$ & $\begin{array}{c}\text { Radom social welfare } \\
\text { beneficiaries }\end{array}$ & $\begin{array}{c}\text { Chełm social welfare } \\
\text { beneficiaries }\end{array}$ \\
\hline 2 people working & 18 & 20 & 22 & 9 \\
\hline 1 person working & 41 & 67 & 67 & 63 \\
\hline Odd jobs & 23 & 0 & 11 & 27 \\
\hline Suport from relatives & 6 & 6 & 0 & 18 \\
\hline Full time job & 0 & 0 & 11 & 9 \\
\hline Otherer activities & 20 & 20 & 0 & 9 \\
\hline
\end{tabular}

Source: own study based on the conducted surveys.

\section{Financial condition of the respondents}

The main measure of the level of household wealth is the income. The level of earnings determines the satisfaction of the current needs of the family and gives the opportunity to accumulate surpluses. The family income includes: income taxed on general terms, income from business activity and untaxed income. The family's financial situa- 
tion is affected not only by the income earned but also by the number of people in the household. Only the income of the whole family divided by the number of its members gives real disposable income per unit.

Table 5. Net income of professionally active families surveyed and social welfare beneficiaries in the month preceding the survey [\%]

\begin{tabular}{|c|c|c|c|c|}
\hline Specification & $\begin{array}{c}\text { Radom working } \\
\text { respondents }\end{array}$ & $\begin{array}{c}\text { Chelm working } \\
\text { respondents }\end{array}$ & $\begin{array}{c}\text { Radom social welfare } \\
\text { beneficiaries }\end{array}$ & $\begin{array}{c}\text { Chelm social welfare } \\
\text { beneficiaries }\end{array}$ \\
\hline Below 1,000 PLN & 30 & 14 & 33 & 18 \\
\hline $1,001-1,500$ PLN & 23 & 6 & 33 & 37 \\
\hline $1,501-2,000$ PLN & 12 & 13 & 12 & 9 \\
\hline $2,001-2,500$ PLN & 29 & 20 & 0 & 9 \\
\hline $2,501-3,000$ PLN & 6 & 14 & 22 & 18 \\
\hline Over 3,000 PLN & 0 & 33 & 0 & 9 \\
\hline
\end{tabular}

Source: own study based on the conducted surveys.

Table 6. Number of people in the surveyed families, including professionally active and social welfare beneficiaries [\%]

\begin{tabular}{|c|c|c|c|c|}
\hline Specification & $\begin{array}{c}\text { Radom working } \\
\text { respondents }\end{array}$ & $\begin{array}{c}\text { Chełm working } \\
\text { respondents }\end{array}$ & $\begin{array}{c}\text { Radom social welfare } \\
\text { beneficiaries }\end{array}$ & $\begin{array}{c}\text { Chelm social welfare } \\
\text { beneficiaries }\end{array}$ \\
\hline 2 & 6 & 13 & 11 & 9 \\
\hline 3 & 18 & 27 & 0 & 18 \\
\hline 4 & 53 & 33 & 67 & 37 \\
\hline 5 & 23 & 20 & 11 & 18 \\
\hline 6 & 0 & 0 & 11 & 18 \\
\hline 7 & 0 & 6 & 0 & 0 \\
\hline
\end{tabular}

Source: own study based on the conducted surveys.

Table 7. Income management in professionally active families and social welfare beneficiaries a month preceding the survey [\%]

\begin{tabular}{|l|c|c|c|c|}
\hline \multicolumn{1}{|c|}{ Specification } & $\begin{array}{c}\text { Radom } \\
\text { working } \\
\text { respondents }\end{array}$ & $\begin{array}{c}\text { Chelm } \\
\text { working } \\
\text { respondents }\end{array}$ & $\begin{array}{c}\text { Radom social } \\
\text { welfare } \\
\text { beneficiaries }\end{array}$ & $\begin{array}{c}\text { Chelm social } \\
\text { welfare } \\
\text { beneficiaries }\end{array}$ \\
\hline We have enough money and we are able to save & 6 & 20 & 22 & 18 \\
\hline We have enough money but we are not able to save & 12 & 20 & 11 & 18 \\
\hline $\begin{array}{l}\text { We live sparingly and thanks to that we have enough } \\
\text { For everything }\end{array}$ & 64 & 40 & 34 & 37 \\
\hline We live sparingly to put aside for more important shopping & 6 & 6 & 0 & 9 \\
\hline We have money only for the cheapest food, clothes and fees & 12 & 14 & 11 & 18 \\
\hline $\begin{array}{l}\text { We have money only for the cheapest food, clothes and fees } \\
\text { But we do not have enough money to pay bills }\end{array}$ & 0 & 0 & 22 & 0 \\
\hline
\end{tabular}

Source: own study based on the conducted surveys. 
According to the above data, it appears that financially independent families had income higher than PLN 2,000 per month - in total, $67 \%$ of respondents in Chełm and $35 \%$ in Radom. These families predominantly created the $2+1$ model $27 \%$ in Chełm and $18 \%$ in Radom), that is, two adults and one child or $2+2(33 \%$ in Chełm and $53 \%$ in Radom) two adults and two children.

Due to the amount of income exceeding the criterion entitling to receive support from the social welfare, i.e. 514 PLN net per person, these families were to maintain financially themselves and the children independently. These families had enough money to satisfy all their needs and they could save some money each month $6 \%$ in Radom and $20 \%$ in Chełm). Although some respondents declared putting aside some funds in the form of deposits, $64 \%$ of families in Radom and $40 \%$ in Chełm, they led economical lives and thanks to that their budgets enabled them to meet their needs. On the other hand, as many as $12 \%$ of the respondents in Radom and $14 \%$ in Chełm indicated that they only had enough money for the cheapest food, clothes and fees. Hence the conclusion that the independently maintaining families had a stable job situation but in most cases their material status allowed only for current purchases of goods and services.

Social welfare beneficiaries were families with low material status, whose income threshold was PLN 2,000 (in total, in Radom 78\%, in Chełm 64\%). Despite low earnings, one household was inhabited by 4 to 7 people ( $89 \%$ in Radom and $73 \%$ in Chelm), and what is important, despite the fact that they needed material support, $18 \%$ of respondents in Radom and 22\% in Chełm declared that the money was enough for all their needs and they still saved. From this fact we can draw the conclusion that the money from social welfare was their additional income, which could have been put aside until later, and not be the support in difficult financial situations.

What is also worth underlining is the fact that the beneficiaries of social welfare were families whose income exceeded PLN 2,000 (22\% of respondents in Radom and $36 \%$ in Chełm). Such situations were the results of two factors: firstly, in a numerically large family, the income criterion was automatically higher, and secondly one member of a family was a disabled person receiving benefits from social assistance because of their illness and not for financial reasons.

In functioning of households, debt is a natural stage in the development resulting from incurring liabilities, including loans and credits. Liabilities are nothing surprising in a household and unavoidable at some stage in life. This is a form of obtaining funds especially on the early life stages of the household, in which the needs for financial resources is the greatest.

According to the survey conducted in $2016,67 \%$ of beneficiaries of social welfare in Radom and $73 \%$ in Chełm did not have any forms of obligations. The remaining $33 \%$ and $27 \%$ of the respondents borrowed money for the renovation of apartments $(22 \%$ of those surveyed in Radom and $0 \%$ in Chełm) and repayment of current liabilities ( $11 \%$ of respondents in Radom, 33\% in Chełm). 
The lack of indebtedness in this group of families can be analyzed first as a advantageous phenomenon, because the lack of financial obligations did not cause additional burdens but also as a disadvantageous fact, because it created lack of investment opportunities in inhibitants capital (education, treatment) and fixed assets (flat, house).

The lending situation of families maintaining the households without financial support from the state budget was different. Active people were aware of their financial needs: the current and the long-term needs. In 2016, loans had been taken out by $33 \%$ respondents in Chełm and $41 \%$ respondents in Radom. According to the analysis of $11 \%$ of families in Radom and $40 \%$ in Chełm, loans were used to repay current liabilities and to purchase household appliances and electronics gadgets $(20 \%$ in Chełm and $60 \%$ in Radom), and thanks to obtaining a mortgage they bought a flat or house that became an investment for the future.

Table 8. Credit situation and their types among economically active people and social welfare beneficiaries [\%]

\begin{tabular}{|l|c|c|c|c|}
\hline \multicolumn{1}{|c|}{ Specification } & $\begin{array}{c}\text { Radom working } \\
\text { respondents }\end{array}$ & $\begin{array}{c}\text { Chelm working } \\
\text { respondents }\end{array}$ & $\begin{array}{c}\text { Radom social welfare } \\
\text { beneficiaries }\end{array}$ & $\begin{array}{c}\text { Chelm social welfare } \\
\text { beneficiaries }\end{array}$ \\
\hline With loans & 41 & 33 & 33 & 27 \\
\hline Without loans & 59 & 67 & 67 & 73 \\
\hline Paying up current liabilities & 11 & 40 & 11 & 33 \\
\hline Others, e.g. renovation, & 22 & 0 & 22 & 0 \\
Buying a house & 0 & 60 & 0 & 0 \\
\hline Purchase of appliances/electronics & 0 & 20 & 0 & 0 \\
\hline
\end{tabular}

Source: own study based on the conducted surveys.

Savings are the most important budget category in home finances because their primary role is to provide a sense of security and inner peace. Having financial comfort, the family does not have to worry about current expenses or job losses. It is much easier to live in such conditions and focus on other valuable areas of life.

On the basis of the study conducted in terms of collecting savings by professionally active people, it can be concluded that they were aware of their financial situation. As many as $55 \%$ respondents in Radom and $46 \%$ in Chełm of families had financial background, including a margin for current expenses and fees, and for securing children's future.

In case of beneficiaries of social welfare in Radom, the approach to savings was short-term, as $33 \%$ of the respondents had some reserve funds only to settle their current liabilities. In Chełm, on the other hand, $27 \%$ of beneficiaries of social welfare declared to have savings, and the reserve funds not only to spend on current fees and expenses, but also on holidays, securing the future of the children and buying or renovating houses. As a result, these people had a higher income than they declared in the social welfare, often as a result of occasional work. 
Table 9. Collecting savings by professionally active people and social welfare beneficiaries [\%]

\begin{tabular}{|c|c|c|c|c|}
\hline Specification & $\begin{array}{c}\text { Radom working } \\
\text { respondents }\end{array}$ & $\begin{array}{c}\text { Chełm working } \\
\text { respondents }\end{array}$ & $\begin{array}{c}\text { Radom social welfare } \\
\text { beneficiaries }\end{array}$ & $\begin{array}{c}\text { Chelm social welfare } \\
\text { beneficiaries }\end{array}$ \\
\hline Yes & 53 & 46 & 33 & 27 \\
\hline No & 47 & 54 & 67 & 73 \\
\hline Total & 100 & 100 & 100 & 100 \\
\hline
\end{tabular}

Source: own study based on the conducted surveys.

Table 10. Types of savings accumulated by professionally active people and social welfare clients [\%]

\begin{tabular}{|l|c|c|c|c|}
\hline \multicolumn{1}{|c|}{ Specification } & $\begin{array}{c}\text { Radom working } \\
\text { respondents }\end{array}$ & $\begin{array}{c}\text { Chelm working } \\
\text { respondents }\end{array}$ & $\begin{array}{c}\text { Radom social welfare } \\
\text { beneficiaries }\end{array}$ & $\begin{array}{c}\text { Chelm social welfare } \\
\text { beneficiaries }\end{array}$ \\
\hline Reserve funds for current expenses & 17 & 20 & 0 & 33 \\
\hline Current payments & 17 & 13 & 100 & 33 \\
\hline Securing future of children & 29 & 20 & 0 & 66 \\
\hline Renovation & 0 & 20 & 0 & 33 \\
\hline House purchase & 6 & 0 & 0 & 100 \\
\hline Others, e.g. holidays & 0 & 0 & 0 & 100 \\
\hline
\end{tabular}

Source: own study based on the conducted surveys.

\section{Spending funds under the 500+ Programme}

In 2014, the social exclusion of children aged $0-17$, measured by the $\mathrm{AROPE}^{2}$ ratio, placed Poland in 15th place among EU countries. A significant reduction of poverty or social exclusion in Poland was observed until the turn of 2008/2009. Similar trends were observed in Great Britain, Ireland and the Netherlands. Despite the decrease of the risk of relative poverty along with taking into account the social transfers in income and in-depth financial deprivation of children in Poland, the rates of these parameters were higher compared to the average in the EU. Despite the fact that Poland experienced favourable social changes in relation to improvement of the living conditions of the youngest population, over the last ten years the threat of poverty or social exclusion of children in Poland was higher than in the EU average (Genowska, Goworko-Składanek,, Szafraniec 2017, p. 16).

Hence, dealing with poverty and improving the living conditions of children and youth under 18 is one of the main goals of Polish family policy. The " $500+$ " pogramme has been designed to serve this purpose.

To assess the effectiveness of the above mentioned programme, there was made the analysis of types of goods and services purchased by professionally active families and social welfare beneficiaries solely to satisfy the needs.

\footnotetext{
${ }^{2}$ The AROPE ratio determines the proportion of the population that experiences at least one of three existential problems in a given calendar year: the risk of relative poverty, increased material deprivation and very low work intensity in households.
} 
Analyzing the types of items purchased for the youngest age group of children, it can be deduced that children with professionally active parents in Chełm and Radom had less access to all necessary goods than children of beneficiaries of social assistance. Only $42 \%$ of parents in Chełm and $55 \%$ of parents in Radom declared the purchase of necessary cleaning supplies. $18 \%$ of children in Chełm and $22 \%$ of children in Radom benefited from paid health care and rehabilitation, and only $14 \%$ of children in Chełm participated in nursery classes.

In the case of social welfare beneficiaries, $50 \%$ in Radom and 100\% in Chełm bought hygienic accessories and food products necessary for the everyday functioning of children. Whereas goods such as paid treatment (only $8 \%$ of parents in Radom and $27 \%$ in Chełm) and the possibility of attending a nursery (only $16 \%$ in Chełm) were treated as unnecessary luxury goods.

Table 11. Goods and services purchased for children aged 0 to 3 years by professionally active families and social welfare beneficiaries a month preceding the survey [\%]

\begin{tabular}{|l|c|c|c|c|}
\hline \multicolumn{1}{|c|}{ Specification } & $\begin{array}{c}\text { Radom working } \\
\text { respondents }\end{array}$ & $\begin{array}{c}\text { Chelm working } \\
\text { respondents }\end{array}$ & $\begin{array}{c}\text { Radom social welfare } \\
\text { beneficiaries }\end{array}$ & $\begin{array}{c}\text { Chelm social welfare } \\
\text { beneficiaries }\end{array}$ \\
\hline Diapers & 55 & 42 & 50 & 100 \\
\hline Modified milk & 33 & 28 & 50 & 50 \\
\hline Paid vaccinations & 44 & 14 & 0 & 16 \\
\hline Toys & 44 & 42 & 75 & 83 \\
\hline Ready-made meals & 11 & 14 & 25 & 33 \\
\hline Medications/treatment & 22 & 28 & 25 & 33 \\
\hline Accessories & 55 & 42 & 25 & 83 \\
\hline Clothes/shoes & 100 & 42 & 75 & 100 \\
\hline Tuition fees for nursery & 0 & 14 & 0 & 16 \\
\hline Rehabilitation & 0 & 14 & 0 & 33 \\
\hline Renovation & 55 & 14 & 0 & 50 \\
\hline
\end{tabular}

Source: own study based on the conducted surveys.

Table 12. Goods and services purchased for children aged 0 to 3 years by professionally active families and social welfare beneficiaries a month preceding the survey [\%]

\begin{tabular}{|l|c|c|c|c|}
\hline \multicolumn{1}{|c|}{ Specification } & $\begin{array}{c}\text { Radom working } \\
\text { respondents }\end{array}$ & $\begin{array}{c}\text { Chelm working } \\
\text { respondents }\end{array}$ & $\begin{array}{c}\text { Radom social welfare } \\
\text { beneficiaries }\end{array}$ & $\begin{array}{c}\text { Chelm social welfare } \\
\text { beneficiaries }\end{array}$ \\
\hline Tuition fees for kindergarten & 80 & 100 & 62 & 85 \\
\hline Tickets for cultural events & 40 & 50 & 50 & 28 \\
\hline Clothes/shoes & 80 & 50 & 37 & 28 \\
\hline Toys & 80 & 66 & 25 & 71 \\
\hline Sport equipment & 20 & 33 & 25 & 57 \\
\hline General development classes & 0 & 16 & 62 & 42 \\
\hline Medications/treatment & 40 & 33 & 12 & 43 \\
\hline Improving housing conditions & 40 & 33 & 0 & 43 \\
\hline
\end{tabular}

Source: own study based on the conducted surveys. 
The above data shows that parents used the funds under the „500+" programme in 2016 mostly for the purchase of clothes, footwear and toys (40\% in Radom and $58 \%$ in Chełm) and fees for kindergarten and additional activities (85\% in Radom and 58\% in Chełm).

Beneficiaries of social welfare in Chełm paid mostly pre-school fees, i.e. $85 \%$, purchased toys and sport equipment, i.e. $64 \%$, and the least children attended paid cultural events, i.e. $28 \%$. In Radom, on the other hand, parents paid for general development classes and tuition fees for kindergarten, i.e. $62 \%$, and purchased medicines and improved housing conditions, i.e. $40 \%$ of the respondents.

Interpreting the above analysis, it can be concluded that both groups: independently managing households and benefiting from social assistance ensured personal development to their children within the limits of their capabilities. As a consequence, the families implemented the main priority of the program - „investment in children's development".

Table 13. Goods and services purchased for children aged 8 to 14 by professionally active families and social welfare beneficiaries a month preceding the survey [\%]

\begin{tabular}{|l|c|c|c|c|}
\hline \multicolumn{1}{|c|}{ Specification } & $\begin{array}{c}\text { Radom working } \\
\text { respondents }\end{array}$ & $\begin{array}{c}\text { Chelm working } \\
\text { respondents }\end{array}$ & $\begin{array}{c}\text { Radom social welfare } \\
\text { beneficiaries }\end{array}$ & $\begin{array}{c}\text { Chelm social welfare } \\
\text { beneficiaries }\end{array}$ \\
\hline Clothes/shoes & 58 & 100 & 87 & 100 \\
\hline School supplies & 100 & 100 & 87 & 85 \\
\hline Books/learning aids & 58 & 33 & 50 & 85 \\
\hline Computer hardware & 16 & 0 & 37 & 57 \\
\hline School dinners & 16 & 33 & 25 & 43 \\
\hline School trips & 58 & 33 & 37 & 85 \\
\hline Medications/treatment & 42 & 0 & 37 & 57 \\
\hline Tickets for cultural events & 66 & 0 & 25 & 43 \\
\hline Trips/camps & 9 & 0 & 25 & 43 \\
\hline Public transport tickets & 16 & 0 & 0 & 44 \\
\hline Sport equipment & 42 & 0 & 25 & 43 \\
\hline Improving housing conditions & 33 & 0 & 0 & 28 \\
\hline Extra classes & 33 & 33 & 37 & 28 \\
\hline Trainings/individual lessons & 25 & 0 & 25 & \\
\hline Rehabilitation & 0 & 0 & 0 & \\
\hline
\end{tabular}

Source: own study based on the conducted surveys.

Analyzing the type of items purchased for children aged 8 to 14 , professionally active parents in Chełm firstly bought clothes and shoes, i.e. 100\%, school supplies and teaching aids, i.e. $66 \%$ and paid for school trips or other organized excursions and additional classes, i.e. $33 \%$. In Radom, on the other hand, $58 \%$ of parents bought clothes and shoes, $79 \%$ of parents bought school supplies and books, $33 \%$ of parents paid for trips and $29 \%$ of parents paid for extra general development classes. 
Beneficiaries of social assistance spent the funds mainly on purchase of clothes and footwear (100\% in Chełm and $87 \%$ in Radom), school supplies, learning aids and computer hardware (58\% in Radom and $90 \%$ in Chełm), on organized trips and sport equipment developing physical culture (29\% of parents in Radom and $85 \%$ in Chełm).

The above analysis shows that the financial situation of children aged 8 to 14 from both groups of families was prosperous. Parents in both cities, thanks to additional funds, had the opportunity to provide children not only basic goods and services, but also could provide entertainment and support personal development.

Table 14. Goods and services purchased for children aged 15 to 18 by professionally active families and social welfare beneficiaries a month preceding the survey [\%]

\begin{tabular}{|l|c|c|c|c|}
\hline \multicolumn{1}{|c|}{ Specification } & $\begin{array}{c}\text { Radom working } \\
\text { respondents }\end{array}$ & $\begin{array}{c}\text { Chelm working } \\
\text { respondents }\end{array}$ & $\begin{array}{c}\text { Radom social welfare } \\
\text { beneficiaries }\end{array}$ & $\begin{array}{c}\text { Chelm social welfare } \\
\text { beneficiaries }\end{array}$ \\
\hline Clothes/shoes & 60 & 100 & 100 & 100 \\
\hline School supplies & 80 & 100 & 50 & 100 \\
\hline Books/learning aids & 80 & 100 & 100 & 100 \\
\hline Computer hardware & 20 & 0 & 100 & 50 \\
\hline School trips & 60 & 0 & 0 & 50 \\
\hline Medications/treatment & 20 & 0 & 0 & 50 \\
\hline Trips/camps & 40 & 0 & 0 & 50 \\
\hline Tickets for cultural events & 40 & 0 & 0 & 0 \\
\hline Public transport tickets & 60 & 0 & 0 & 0 \\
\hline Improving housing conditions & 20 & 0 & 0 & 0 \\
\hline Extra classes & 20 & 0 & 0 & 0 \\
\hline
\end{tabular}

Source: own study based on the conducted surveys.

Analyzing the type of shopping done for the young people aged 15 to 18, professionally active parents in Chełm purchased only clothes and footwear and school supplies and teaching aids, i.e. $100 \%$. In case of Radom residents, parents purchased all kinds of goods and services, including clothes and shoes i.e. $60 \%$, school aids, computer equipment and public transport tickets, i.e. $60 \%$. They also allowed children to take part in excursions and other events, i.e. $50 \%$, provided access to extra activities, i.e. $20 \%$, private treatment, i.e. $20 \%$ and improved the housing conditions of children, i.e. $20 \%$ of the respondents.

Beneficiaries of social assistance in Chelm purchased in particular clothes and footwear, i.e. $100 \%$, teaching aids and computer equipment, i.e. $83 \%$, school trips and holiday trips, i.e. $50 \%$ and private treatment, i.e. $50 \%$. Radom residents, on the other hand, bought clothes, footwear and computer equipment in 100\%, and learning aids in $75 \%$.

The above analysis shows that financial situation of the young people aged 15 to 18 was the best in the professionally active families in Radom and beneficiaries of social assistance in Chełm. Thus, it can be concluded, that the inhabitants of Radom had 
a stable financial situation, and the funds from the „500+” programme were additional income. The inhabitants of Chełm, although declared a difficult financial situation, they were able to provide children with a high standard of living. So it can be stated that their actual financial situation was not too difficult or these families were not able to manage the household budget properly by consuming it instantly.

\section{Summary}

Parents who were professionally active undertook well-thought-out and rational decisions concerning household budget, including funds from the „500+” programme. They also skilfully managed financial surpluses obtained from making accurate purchases of goods and services and thanks to loans taken out sensibly, e.g. on reasonable terms.

Beneficiaries of social assistance, however, made purchases impulsively without a deeper thought, they often bought expensive and unnecessary goods and services. These families were also characterized by a lack of efficiency in the functioning of the financial market because in most cases they declared the lack of loans and deposits.

Thus, the following conclusion can be drawn: only the appropriate education, the ability to manage finances and professional stability gives family financial security.

\section{References}

Act of 11 February 2016 on State aid in bringing up children; Journal of Laws 2016 item 195, art. 4-6.

Arak P. (2016), Pro-family policy in Poland and around the world, Central European Financial Observer.

Durasiewicz A. (2009). Instrumenty polityki rodzinnej, Biuletyn informacyjny wiadomości społeczne, pod red. Głąbickiej K., Politechnika Radomska, ROR PTPS, Radom.

Durasiewicz A. (2014). Kierunki rozwoju polityki rodzinnej w Polsce - dylemat społeczny zachodzących zmian i wyzwań na przyszłość, [w:] Polityka społeczna wobec wyzwań i zmian zachodzących we współczesnym świecie, pod red. Kubiaka M., Wydawnictwo UG, Gdańsk.

Durasiewicz A. (2017). W kierunku rozwoju polityki rodzinne w Polsce, Wydawnictwo WSzP, Warszawa.

Genowska A., Goworko-Składanek B., Szafraniec K. (2017). Społeczno-ekonomiczne warunki bytowe dzieci w Polsce na tle krajów Unii Europejskiej. Część I, Wydawnictwo Medycyna Ogólna i Nauki o Zdrowiu, nr 1, t. 23, Białystok.

Giza-Poleszczuk A. (2005). Rodzina, a system społeczny. Reprodukcja i kooperacja w perspektywie interdyscyplinarnej, Instytut Socjologii UW, Warszawa.

Glabicka K. (2014). The role of social services in the 21st century, Central European Review of Economics \& Finance, Vol. 6, № 3. 
Głąbicka-Auleytner K. (2016). Znaczenie usług społecznych dla lokalnej polityki społecznej, Wydawnictwo UTH, Radom.

Głąbicka-Auleytner K., Gagacka M., Borek J. (2017). Nowe oblicza lokalnej polityki społecznej, Wydawnictwo UTH, Radom.

Golinowska S. (2007). Rodzinna a przemiany rodziny, gospodarki i państwa, głos w debacie o Polityce Rodzinnej w Polsce, Instytut Pracy i Spraw Socjalnych, Polityka Społeczna 8.

Golinowska S., Sowa-Kofta A. (2017). Combating Poverty Through Family Cash Benefits. On the first results of the Program „Family 500+", in Poland, Polityka Społecza 1.

Kiełczewska I.,Brandt N. (2018). The „Family 500+” Child allowance and female labour supply in Poland, lbs Working Paper 01.

Kulczyk M.(2016). Family rights and family policy in Poland, Research fellow at the ECLJ.

Myck M., (2016). Estimating Labour Supply Response to the Introduction of the Family 500+ Programme, CenEA Working Paper Series 0.1

Radzik P. (2017). The influence of the government Family 500+ programme on the female labour force participation rate VIII International Scientific Conference Analysis of International Relations, Katowice.

Sowa A. (2016). „Family 500+”: A new family income-supporting benefit in Poland - European Social Policy Network, ESPN Flash Report 45. 